\title{
COMMENT OPEN WastePD, an innovative center on materials degradation
}

\author{
Gerald S. Frankel ${ }^{1}$, John Vienna ${ }^{2}$ and Jie Lian $^{3}$ \\ npj Materials Degradation (2017)1:5; doi:10.1038/s41529-017-0002-5
}

The US Department of Energy recently awarded funds to create the Center for Performance and Design of Nuclear Waste Forms and Containers (WastePD) as part of the Energy Frontier Research Center (EFRC) program. EFRCs are multi-investigator collaborations of universities, national labs, and companies that "conduct fundamental research focusing on one or more "grand challenges" and use-inspired "basic research needs" identified in major strategic planning efforts by the scientific community." ${ }^{1}$ The major performance parameter of nuclear waste forms is their ability to isolate the radionuclides by withstanding degradation in a repository environment over very long periods of time. So WastePD is at heart a center focused on materials degradation.

In the USA, there are two main sources of nuclear waste: spent nuclear fuel from commercial reactors composed of uranium metal or oxide, and the legacy of the nuclear weapons program existing as liquid/solid mixtures in underground steel tanks in Hanford, WA, and Savannah River, SC. The tank waste will mostly be mixed with molten borosilicate glass and cast into stainless steel canisters. Some radionuclides in the tank waste are not suitable for mixing into glass, and will instead be isolated in ceramic or metal waste forms. All of the waste will be placed in corrosion resistant metallic containers and eventually transferred to a permanent mined underground repository. It should be noted that the repository program in the US, which is dictated by current US Law to be located at the Yucca Mountain site in Nevada, was defunded by the Obama administration. The Trump administration has not yet indicated how it intends to proceed on this important topic, but it is possible that the Yucca Mountain Project will be restarted or that a new location for a repository will be sought.

It is evident that nuclear waste in the repository and its containers will take these three forms of solid matter: glass, metal, and ceramic, and all three can degrade during exposure to the environment. Glasses and ceramics are often considered to be nonreactive and corrosion resistant, but they do degrade. ${ }^{2-4}$ When exposed to water, glass reacts to form an alteration layer on its surface that protects the glass and slows the rate of attack. In some environments, however, this protective layer becomes unstable and the glass exhibits an accelerated rate of attack. The details of the exact nature and stability of the protective layer are not known, and the transition to a non-protective condition cannot be predicted. As a result, current repository performance models take a conservative approach by assuming that glass will corrode at an accelerated rate rather than the slow passive rate. $\mathrm{A}$ better understanding of the glass corrosion process could provide more robust repository models and influence the repository design. Ceramic waste forms can also release the incorporated radionuclides during interaction with the environment through matrix dissolution, selective leaching, radionuclide diffusion, and surface reaction. An alteration phase may also form on the surface of ceramic waste forms to protect against further corrosion. Furthermore, many of the ceramic hosts under consideration for nuclear waste are semi-conductive and therefore can undergo transformative electrochemical reactions in aggressive environments. The environmental degradation of ceramic waste forms has not been studied in detail to date and little is known about the phenomena involved. ${ }^{4}$ By their nature, metals are often susceptible to corrosion, although extremely corrosion resistant alloys (CRAs) have been developed by the judicious combination of alloying elements and prescribed processing. These alloys, such as the Ni-based Alloy 22 that was planned as the canister material for Yucca Mountain, ${ }^{5-7}$ are protected by the spontaneous formation of a very thin surface oxide layer known as a passive film. However, such nanometer-thick films can break down and lead to accelerated forms of corrosion. It is still not clear whether the corrosion protection of CRAs stems primarily from the ability of the passive film to resist breakdown or from its ability to reform when breakdown does occur. Thus, it is clear that there are unifying concepts in the degradation of the three materials classes of waste forms.

WastePD involves 13 principal investigators from nine institutions, and is based at The Ohio State University in Columbus, $\mathrm{OH}$, USA. The other institutions include universities (University of Virginia, Penn State University, Louisiana State University, Rensselaer Polytechnic Institute, and University of North Texas), national labs (Pacific Northwest National Lab and the French Center for Atomic Energy, CEA) and one company (QuesTek Innovations). The Pls are divided into three teams focused on glass, ceramic, and metal degradation, respectively. WastePD is the first center ever created to address the degradation of this diverse group of materials in a comprehensive and coordinated manner. These teams are tied together by synergistic activities in the areas of computation, commonalities, and materials design. The three teams and unifying synergistic activities are illustrated schematically in Fig. 1. Synergistic collaborations are a critical component of every EFRC as they are required for making the output of a large center more than the sum of its individual components. It is expected that, for WastePD, the interactions of experts in each of the forms of matter will create new approaches and understanding that would not have been possible otherwise.

Materials design has evolved in recent years from a trial-anderror process to concepts based on Integrated Computational Materials Engineering (ICME), which uses models of the fundamental underlying science to predict material properties. ${ }^{8}$ ICME concepts have not been applied to CRAs or nuclear waste glass and ceramics. It should be noted that, although it is "use-inspired," the

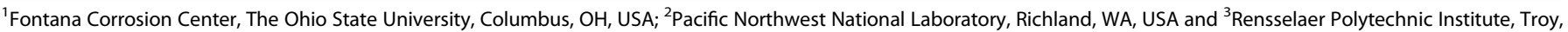
NY, USA

Correspondence: Gerald S. Frankel (frankel.10@osu.edu)

Received: 6 December 2016 Accepted: 8 December 2016

Published online: 25 July 2017 


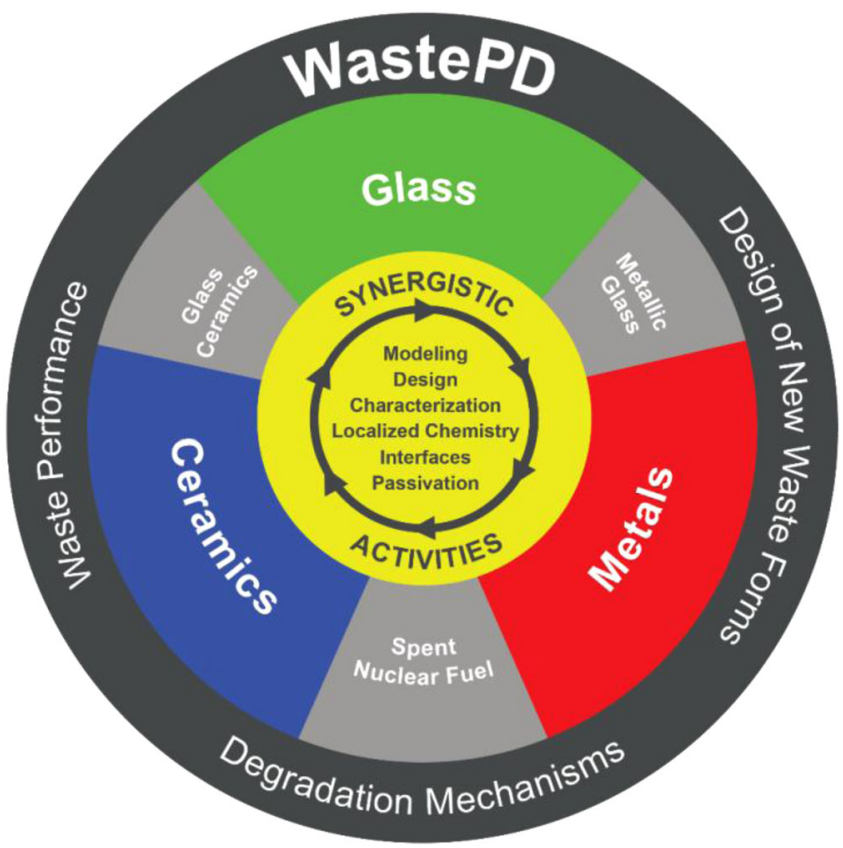

Fig. 1 Schematic representation of the organization of WastePD

research supported by the EFRC program must be very fundamental in nature. As such, the goals of WastePD are not to develop new materials to be used as nuclear waste forms. Rather, this center will generate the fundamental understanding of the degradation mechanisms of the waste forms and the innovative ICME design strategies that will facilitate the subsequent development of new materials with improved properties. This understanding will also provide DOE the tools to prevent environmental contamination and to explore totally new disposal concepts.

\section{ACKNOWLEDGEMENTS}

This work was supported as part of the Center for Performance and Design of Nuclear Waste Forms and Containers, an Energy Frontier Research Center funded by the U.S. Department of Energy, Office of Science, Basic Energy Sciences under Award \# DESC0016584.

\section{ADDITIONAL INFORMATION}

Competing interests: The authors declare that they have no competing financial interests.

Publisher's note: Springer nature remains neutral with regard to jurisdictional claims in published maps and institutional affiliations.

\section{REFERENCES}

1. http://science.energy.gov/bes/efrc/. Accessed 16 Jun 2017.

2. Cailleteau, C. et al. Insight into silicate-glass corrosion mechanisms. Nature Mat. 7, 978-983 (2008)

3. Vienna, J. D., Ryan, J. V., Gin, S. \& Inagaki, Y. Current understanding and remaining challenges in modeling long-term degradation of borosilicate nuclear waste glasses. Int. J. Appl. Glass Sci. 4, 283-294 (2013).

4. National Research Council of the National Academies. Waste Forms Technology and Performance: Final Report, Committee on Waste Forms Technology and Performance. The National Academies Press, Washington, DC. ISBN 978-0-309-18733-6 (2011).

5. Gordon, G. M. F.N. Speller award lecture: corrosion considerations related to permanent disposal of high-level radioactive waste. Corrosion 58, 811-825 (2002).

6. Kehler, B. A., llevbare, G. O. \& Scully, J. R. Crevice corrosion stabilization and repassivation behavior of alloy 625 and alloy 22. Corrosion 57, 1042-1065 (2001).

7. Mishra, A. K. \& Frankel, G. S. Crevice corrosion repassivation of alloy 22 in aggressive environments. Corrosion 64, 836-844 (2008).

8. Olson, G. B. Designing a new material world. Science 288, 993-998 (2000).

(i) Open Access This article is licensed under a Creative Commons adaptation, distribution and reproduction in any medium or format, as long as you give appropriate credit to the original author(s) and the source, provide a link to the Creative Commons license, and indicate if changes were made. The images or other third party material in this article are included in the article's Creative Commons license, unless indicated otherwise in a credit line to the material. If material is not included in the article's Creative Commons license and your intended use is not permitted by statutory regulation or exceeds the permitted use, you will need to obtain permission directly from the copyright holder. To view a copy of this license, visit http://creativecommons. org/licenses/by/4.0/.

(c) The Author(s) 2017 